\title{
Oblicza Ireny Sendlerowej. Wizerunek Sprawiedliwej wśród Narodów Świata w relacjach uratowanych przez nią dzieci oraz w debacie publicznej po roku 2000
}

\author{
KATARZYNA SUSZKIEWICZ ${ }^{1}$ \\ ${ }^{1}$ Uniwersytet Jagielloński, ul. Narutowicza 11, 31-221 Kraków. ORCID: 0000-0003-2548-1632, Email: \\ suszkiewicz.katarzyna@gmail.com
}

STRESZCZENIE: Artykuł ${ }^{1}$ ma na celu analizowanie przemian wizerunku Ireny Sendlerowej - Sprawiedliwej wśród Narodów Świata, działaczki Rady Pomocy Żydom „Żegota”. W pracy uwypuklone zostały dwa oblicza Sendlerowej: matczyne, takie, jakie zachowały w pamięci uratowane przez nią dzieci oraz heroiczne - wykreowane w przestrzeni publicznej po roku 2000. W artykule jej postać ukazana została na tle przemian w postrzeganiu relacji polsko-żydowskich w Polsce.

SŁOWA KLUCZOWE: Irena Sendlerowa, dzieci, Sprawiedliwa wśród Narodów Świata, Holokaust, ratowanie

Córka, Janina Zgrzembska, gdy rodzinie było ciężko żyć w latach 60., zapytała kiedyś: - Mamo, co ty takiego zrobiłaś, że my cierpimy? Wnuczka Agnieszka, dwadzieścia lat później, zdziwiona wizytą zagranicznej telewizji, zadała inne pytanie: - Babciu, co ty takiego zrobiłaś, że będziesz sławna? (Mieszkowska 2009: 23)

\footnotetext{
${ }^{1}$ Artykuł powstał w ramach projektu badawczego Europeanization of realms of memory and the invention of a common European heritage pod opieką prof. dr hab. Zdzisława Macha. Projekt został sfinansowany ze środków Narodowego Centrum Nauki przyznanych na podstawie decyzji numer DEC-2013/08/M/ HS6/00041. Bardzo dziękuję Justynie Arabskiej za lekturę i cenne uwagi na temat poniższego artykułu.
} 


\section{WPROWADZENIE}

Kim była Irena Sendlerowa? A może raczej jak była i jest postrzegana? Celem poniższego artykułu jest nie tylko przybliżenie biografii polskiej Sprawiedliwej wśród Narodów Świata, ale raczej spojrzenie na jej losy poprzez pryzmat wspomnień uratowanych przez nią dzieci i wzrostu zainteresowania jej osobą w dyskursie publicznym w Polsce po roku 2000. Biografia Sendlerowej staje się tutaj bowiem jedynie pretekstem do przedstawienia pewnych reprezentacji i mitów narosłych przez lata wokół jej postaci.

Artykuł rozpoczyna się od zaprezentowania skomplikowanego systemu ratowania i możliwych sposobów ocalenia dzieci żydowskich w czasie Holokaustu. Następnie przytoczone są historie wybranych dzieci oraz zacytowane ich wspomnienia związane z Ireną Sendlerową. Przechodząc do drugiej części artykułu, wyjaśnione zostają powody, dla których osoba Sendlerowej była zapomniana w czasach PRL-u oraz wskazany zostaje moment swoistego „odkrycia” jej postaci przez amerykańskie uczennice z Kansas. Ostatnią część artykułu stanowi przedstawienie różnorodnych inicjatyw służących rozpowszechnianiu heroicznego obrazu tej Sprawiedliwej.

W artykule zanalizowany został materiał zastany: literatura przedmiotu, wspomnienia uratowanych przez Sendlerową dzieci, artykuły prasowe oraz materiał audiowizualny. We wszystkich źródłach poszukiwane były fragmenty charakteryzujące tytułową bohaterkę oraz odnoszące się do jej postaw i działań wobec ratowanych Żydów. Treści te były poddane analizie pod kątem biograficznym i literackim.

W poniższej pracy uwypuklone zostały dwa wizerunki Ireny Sendlerowej. Z jednej strony mamy do czynienia z obrazem kobiety, jaki zachowały w swojej pamięci uratowane przez nią dzieci. Nie jest to obraz kompletny, gdyż należy tutaj jasno podkreślić, że choć Sendlerowej przypisuje się uratowanie ponad 2500 dzieci żydowskich, to de facto w ich ratowanie była zaangażowana cała grupa osób, a Sendlerowa z czasem stała się tylko, a raczej aż, symbolem tej grupy. Sendlerowa nigdy oficjalnie nie przypisywała jedynie sobie zasługi ratowania dzieci, było wręcz odwrotnie. Wielokrotnie twierdziła: Robiłam to, co nakazywało mi sumienie. Sama nic bym nie zrobiła (Grubowska 2014: 28). Niemożliwe jest dotarcie do wszystkich osób, którym Sendlerowa pomogła, co powoduje, że niemożliwe staje się także stworzenie jej kompletnego portretu. Nie wszystkie też osoby składały świadectwo na temat własnego ocalenia. Wiele spośród tych dzieci dopiero po wojnie dowiedziało się, że Irena Sendlerowa brała w nim udział. Również dopiero po wojnie wiele z nich nawiązało osobisty kontakt ze Sprawiedliwą. Ten pierwszy wizerunek jest portretem matki - pełnym ciepła, oddania, poświęcenia i miłości. W ten sposób Sendlerową pamiętają Michał Głowiński, Katarzyna Meloch, Piotr Zettinger czy Elżbieta Ficowska. Wybór wypowiedzi powyżej wymienionych osób nie jest przypadkowy. Są to osoby, które wielokrotnie przywoływały postać Sendlerowej, znały ją osobiście i miały świadomość, że zostały ocalone także dzięki jej pomocy. Powyższa selekcja pozwoliła także na pokazanie kompleksowości oraz trudności funkcjonowania całego systemu ratowania dzieci w czasie Holokaustu.

O ile w czasie wojny Irena Sendlerowa była osobą ważną, kierowniczką referatu dziecięcego w Radzie Pomocy Żydom „Żegota”, o tyle jej działania i zasługi w czasie PRL-u odeszły w niepamięć. Zarówno ówczesny ustrój polityczny, jak i jej osobiste 
losy i poświęcenie się pracy zawodowej nie pozwoliły na wspominanie heroizmu. Pamięć o Żydach była wtedy poza kręgiem społecznego i politycznego zainteresowania. Dopiero na początku XXI wieku, dzięki czterem uczennicom z Kansas w USA, wojenna historia Sendlerowej została przypomniana w Polsce a jej wizerunek w świadomości publicznej zaczął się zmieniać. Proces ten doskonale wpisuje się w dynamicznie rozwijającą się sytuację Polski, w której, po upadku komunizmu, podejmowano próby rozliczenia z trudną przeszłością relacji polsko-żydowskich. Jednocześnie na ten sam okres przypadło wzmożone zainteresowanie Unii Europejskiej sprawami upamiętnienia Holokaustu i kwestii pamięci o ludobójstwie. Irena Sendlerowa stała się symbolem oporu, sprawiedliwości i bohaterstwa. Jednak obraz ten również wydaje się być uproszczony i niepełny. Nie tylko poprzez skoncentrowanie na jednostce, a pomijaniu istnienia struktur, w których Sendlerowa funkcjonowała. Jej wizerunek zaczął pełnić funkcję przeciwwagi do negatywnych postaw Polaków wobec Żydów podczas II wojny światowej.

Zestawienie obu wizerunków miało na celu odniesienie się do dwóch sfer, w których Irena Sendler funkcjonowała: sfery prywatnej, rodzinnej, intymnej oraz sfery publicznej. Warto tutaj zaznaczyć, że oba wykreowane wizerunki nie były zgodne z postrzeganiem Sendlerowej przez samą siebie - o ile trudno znaleźć jej wypowiedzi, w których mówi o sobie jako o matce ratowanych dzieci, o tyle podczas wielu okazji podkreślała, że nie postrzega samej siebie jako bohaterki. Zestawienie obu powyższych płaszczyzn dobitnie pokazuje, że wykreowane z czasem wizerunki Sendlerowej zaczęły funkcjonować poza nią samą. Pomiędzy tymi obrazami istniała realna postać Ireny Sendlerowej. Warto rozpocząć analizę od przybliżenia jej biograficznych losów.

Irena Sendlerowa (Krzyżanowska) urodziła się w Warszawie 15 lutego 1910 roku. Matka Ireny - Janina z Grzybowskich pochodziła z domu o tradycjach niepodległościowych, a ojciec - Stanisław Krzyżanowski był lekarzem i działaczem Polskiej Partii Socjalistycznej (Grubowska 2014: 12). Dzięki pomocy siostry i szwagra, Krzyżanowski otworzył sanatorium przeciwgruźlicze. Sendlerowa wspomina ten okres następująco: Mój dom rodzinny był zawsze otwarty dla wszystkich potrzebujących. Każdy mógł przyjść ze swoimi kłopotami i otrzymać pomoc. Biedna ludność, zarówno polska jak i żydowska. Tata leczył bezpłatnie, dając nawet leki za darmo. (...) W mojej pamięci została nasza rodzina jako bardzo się kochająca i otwarta dla wszystkich potrzebujących (Mieszkowska 2009: 65).

Michał Głowiński, uratowany przez Irenę Sendlerową jako dziecko, podkreśla, że to przede wszystkim pochodzenie i atmosfera domu, w jakim się wychowała, ukształtowały ją na całe życie i miały kluczowy wpływ na jej moralne wybory. Pisze on: (...) nie można jednak zapominać, skąd pochodziła i jak formował się jej charakter. (...) To ideowe zaplecze i doświadczenie $w$ działaniu na rzecz tych, którzy potrzebują pomocy, okazały się bezcenne wtedy, gdy jako jedna z pionierek $w$ tej dziedzinie zaangażowała się w czasie Zagłady w ratowanie Żydów (Grubowska 2014: 7-8). I na innym miejscu dodaje: Gdybym pisat o pani Irenie Sendlerowej hasło do encyklopedii i miał ją określić słowami krótkimi i najprostszymi, powiedziałbym: Wielka Działaczka Społeczna, myślę bowiem, że w nich wyraża się istota Jej życia $i$ wszystkich trudów, jakie w ciagu dziesięcioleci podejmowała. Wywodzi się z demokratycznej lewicy, odgrywającej od drugiej połowy XIX wieku ogromna 
rolę w polskim życiu, a przede wszystkim z tej jej części, której przedstawiciele dużo bardziej niż polityka zajmowali się praca na rzecz biednych, upokorzonych i upośledzonych. (...) Jej niezwykła, przynosząca tak imponujące rezultaty działalność w czasie Zagłady stanowi prosta konsekwencje tego, w czym wyrosła i co robiła w latach poprzedzajaccych. Tutaj stawka się zwiększyła, bo chodziło o ratowanie ludzkiego życia (Mieszkowska 2009: 293).

Irena Sendlerowa planowała kształcić się w kierunku pracy społecznej, jednak w Polsce w tamtym czasie nie było studiów o tym profilu. Początkowo Sendlerowa rozpoczęła studia prawnicze na Uniwersytecie Warszawskim, ale po dwóch latach przeniosła się na polonistykę (Grubowska 2014: 13). Lata trzydzieste XX wieku charakteryzowały się wzrostem wystąpień antysemickich. Irena Sendlerowa czynnie sprzeciwiała się wszelkim przejawom antysemityzmu, co nie pozostawało bez konsekwencji. Raz została uderzona w twarz przez członka ONR-u (ONR - Obóz Narodowo-Radykalny., narodowo-radykalne ugrupowanie ideowe w latach 30-tych), kiedy nie chciała podporządkować się zasadom tzw. getta ławkowego (Getto ławkowe - forma wykluczenia w latach 30-tych stosowana na polskich uniwersytetach polegająca na wydzieleniu części sali dla studentów i studentek pochodzenia żydowskiego) i stała razem z Żydami. W proteście przeciwko agresji wobec Żydów (była świadkiem ciągnięcia Żydówki za włosy z drugiego piętra na parter) wykreśliła w swoim indeksie adnotację „strona polska”, za co została zawieszona w prawach studenta. Dopiero w 1939 roku powróciła na studia dzięki interwencji profesora Tadeusza Kotarbińskiego, który chwilowo zastępował rektora (Mieszkowska 2009: 73-74). Jej filosemicka postawa przyczyniła się do późniejszego budowania jej bohaterskiego mitu.

Już od lat wczesnej młodości Sendlerowa przejawiała skłonności do opieki nad innymi i podejmowania się działań na rzecz ludzi wykluczonych, ubogich oraz dzieci. Okresem, kiedy właśnie te cechy jej charakteru stały się kluczowe dla podejmowanych przez nią działań był czas II wojny światowej. W poniższym podrozdziale przedstawione zostaną działania Ireny Sendler podczas Holokaustu poprzez pryzmat wspomnień uratowanych przez nią dzieci. Możemy powiedzieć, że czas ten to dominacja obrazu Sendlerowa jako matki-Polki, opiekunki, ratowniczki ocalającej dzieci (zwłaszcza dzieci żydowskie) przed nieuchronną śmiercią, na które zostały skazane według założeń nazistowskiej propagandy.

\section{OBLICZE MATCZYNE}

Matka, to osoba, która według powszechnego mniemania, przede wszystkim troszczy się o dobrą jakość życia dla swoich dzieci. Jest zorganizowana, skrupulatna, pracowita, życzliwa i darzy swoje potomstwo miłością. Niewątpliwie ważna w archetypicznym obrazie matki jest zdolność do poświęceń dla innych (Bogucka 2014: 449-452). Analizując matczyne oblicze Ireny Sendlerowej możemy znaleźć każdą z tych cech. Podejmowała ona wysiłki, żeby pomóc ratować żydowskie dzieci podczas Holokaustu, zapewnić im jak najlepszą kryjówkę i warunki schronienia. Razem ze swoimi współpracownikami w pocie czoła pracowała na rzecz podopiecznych, a po wojnie z niektórymi dziećmi nadal utrzymywała kontakt i interesowała się ich losami.

W 1932 roku Sendlerowa rozpoczęła pracę w Sekcji Pomocy Matce i Dziecku przy 
Obywatelskim Komitecie Pomocy Społecznej. Do jej obowiązków należało przeprowadzanie wywiadów środowiskowych, świadczenie w sądach i opieka nad matkami nieślubnych dzieci. W 1935 roku po zlikwidowaniu Sekcji pracowała w różnych działach Wydziału Opieki Społecznej zarządu miasta Warszawy (Mieszkowska 2009: 7576, zob. Engelking, Leociak 2001: 234-333). Czas ten Sendlerowa wspomina następująco: Od pierwszych dni mojej pracy byłam zachwycona wspaniałą atmosfera życzliwości, tolerancji, miłości do każdego człowieka, rozpowszechnianiem na cały świat idei dobra i sprawiedliwości społecznej. Tą atmosferą zachłysnęłam się całkowicie (Mieszkowska 2009: 75).

Od samego początku okupacji Niemcy nakazali zwolnienie żydowskich pracowników w zarządzie miasta Warszawy oraz zakazali pomocy biedocie żydowskiej. Pomimo tego zakazu Sendlerowa wraz z zaufanymi osobami (byli to m.in.: Jan Dobraczyński - przełożony Sendlerowej w Referacie Opieki nad Dzieckiem, Irena Schultz, Jadwiga Deneka i Jadwiga Piotrowska) zorganizowali komórki pomocy Żydom. Działalność ta wiązała się z fałszowaniem dokumentów oraz podrabianiem podpisów, a z czasem stawała się coraz bardziej skomplikowana w związku z problemem legalnego wejścia do getta. Problem ten został rozwiązany dzięki życzliwości i pomocy dra Juliusza Majakowskiego pełniącego funkcję dyrektora Zakładów Sanitarnych, który wystawił Sendlerowej i Schultz fałszywe legitymacje służbowe oraz przepustki do getta. To również dzięki licznym znajomościom Sendlerowej zarówno w getcie jak i po aryjskiej stronie udało się zorganizować sprawnie pomoc. Na podstawie fałszywych dokumentów z Wydziału Opieki dla mieszkańców getta przemycano: pieniądze, żywność, lekarstwa i odzież. W celu uniknięcia wzmożonych kontroli okupanta pracownicy Wydziału Opieki nawiązali kontakty z administratorami i dozorcami domów (Bartoszewski, Lewinówna 2007: 96-97, por. Grubowska 2014: 39, por. Mieszkowska 2009: 90).

W pierwszym okresie wojny, do 1942 roku, pomoc udzielona Żydom przez Sendlerową i jej współpracowników nie była związana z żadną konkretną instytucją. Sytuacja ta uległa zmianie po powstaniu Rady Pomocy Żydom „Żegota” (zob. Kunert 2002). Sendlerowa wspomina: Warto bowiem podkreślić, że nie działaliśmy w imieniu jakiejś organizacji, chociaż wielu z nas należało do różnych ugrupowań politycznych. Nasza akcja pomocy Żydom zrodziła się samorzutnie już w pierwszych dniach okupacji jako następstwo konkretnej sytuacji. Ludzie, którzy się w niej angażowali, czynili to z pobudek humanitarnych; był to odruch ludzki, który nakazywał nie pozostawać biernym w obliczu największego barbarzyństwa w stosunku do naszych żydowskich współobywateli. „Żegota” natomiast znalazła $w$ nas poważny punkt oparcia, większa grupę ofiarnych, wypróbowanych $w$ tej działalności ludzi, z szeroko rozgałęzionq̨ siatka kontaktów w getcie i po „aryjskiej” stronie (Bartoszewski, Lewinówna 2007: 97-98). To właśnie z „Żegotą” i stojącym na jej czele Julianem Grobelnym (ps. Trojan) skontaktowała Sendlerową koleżanka Stefania Wichlińska, co niewątpliwie miało znaczący wpływ na losy tytułowej bohaterki niniejszego artykułu (Mieszkowska 2009: 141 i nast.).

Władysław Bartoszewski opisując swoją aktywność w „Żegocie” tak przedstawia postać Ireny Sendlerowej: Realizacja najniezbędniejszych zadań była pewnym mierzeniem sił na zamiary i wymagała nie tyle gotowości do ryzyka, ale też energii graniczacej $z$ przebojowością, umiejętności nawiązywania kontaktów z ludźmi, uporu i cierpliwości. A 
przy tym przecież rozwagi i czujności. (...) Nieoceniona wręcz rolę odgrywali pracownicy Wydziału Opieki Społecznej Zarządu Miejskiego: dla mnie symbolizowała tę pracę przede wszystkim „Jolanta” czyli Irena Sendlerowa, jeszcze przed powstaniem Rady uczestniczaca $w$ akcji ratowania dzieci żydowskich; „Trojan” korzystał z jej pracy w pionie PPS-WRN, a od wczesnej jesieni 1943 roku powierzono jej oficjalnie kierowanie Referatem Dziecięcym Rady, prowadzonym wcześniej przez Aleksandrę Dargielowa (Bartoszewski 2015: 132).

Do zadań Referatu należała opieka nad osieroconymi bądź oddzielonymi żydowskimi dziećmi, umieszczanie ich w relatywnie bezpiecznych kryjówkach (szpitalach, sierocińcach, klasztorach, u polskich rodzin) oraz udzielanie im stałej pomocy (medycznej, rzeczowej bądź finansowej). Praca ta w swojej istocie nie różniła się od działań, które Sendlerowa wraz z innymi wykonywali już nielegalnie w Referacie Opieki, jednak przynosiła ze sobą dodatkowe ryzyko. W dniu 20 października 1943 roku do domu Sprawiedliwej wkroczyło gestapo. Jedyną myślą było ukrycie skrupulatnie prowadzonej kartoteki z prawdziwymi danymi ukrywanych żydowskich dzieci oraz adresami ich pobytu. Listę ukryła Janina Grabowska, a Sendlerowa została zabrana na Pawiak, gdzie była brutalnie przesłuchiwana i torturowana przez trzy miesiące. Dzięki głębokiej konspiracji trudno było dotrzeć do osób, które mogły pomóc Sendlerowej i wydostać ją z więzienia, co ostatecznie udało się przedstawicielom „Żegoty” (Sytuację te potwierdza w swoim oświadczeniu z 20 kwietnia 1963 roku Helena Grobelny, żona Juliana Grobelnego ps. Trojan. Za: Mieszkowska 2014: 199-200, por. Górny 2013: 186-189, Bartoszewki, Lewinówna 2007: 105-106, Mieszkowska 2009: 181-194), którzy zdecydowali się na potajemne wykupienie Sendlerowej z rąk gestapo, gdyż była ona bezcennym źródłem informacji dla organizacji. Tylko ona prowadziła kartotekę ukrywanych dzieci i znała ich adresy pobytu (Grubowska 2014: 66).

Warszawskie getto było przestrzenią działalności konspiracyjnej Ireny Sendlerowej. Michał Głowiński opisuje je w następujący sposób: Getto pozostaje w mojej pamięci przestrzenią bezkształtna, pozbawiona idei porządkującej, przestrzenią, której odebrano - obwodzac murami - sens, tak jak odebrano sens życia ludziom, których $w$ nia wtłoczono. Zapamiętałem jednak jej kolor, swoisty i niepowtarzalny, taki, jakim się odznacza być może każde zbiorowe nieszczęście. Kolor szaro-brunatno-czarny, jedyny w swoim rodzaju, wyzbyty jakiejkolwiek żywszej barwy, jakiegokolwiek urozmaicajaccego akcentu. Pozostała mi przed oczami monochromatyczność getta, najlepiej chyba określa ją słowo „wyszarzałość" (Głowiński 2014: 9).

W tej przestrzeni rozgrywały się prawdziwe ludzkie dramaty. W swoich wspomnieniach Sendlerowa przywołuje sceny rozstań rodziców z dziećmi w getcie, kiedy miały zostać z niego uratowane. Niekończące się pytania o szanse przeżycia dla dzieci, z jednej strony, jakże naturalne ze strony rodziców, a z drugiej absurdalne i niemożliwe do przewidzenia w tamtej, wojennej rzeczywistości. Docierałyśmy też z koleżankami do rodzin, o których wiedziałyśmy, że mają dzieci - wspomina pani Irena - mówiłyśmy, że mamy możliwość ich ratowania, wyprowadzając za mury. Wówczas padało zasadnicze pytanie o gwarancje powodzenia naszej akcji. Trzeba było uczciwie powiedzieć, że żadnej gwarancji dać nie możemy. Mówiłam szczerze, że nie wiem nawet czy ja dzisiaj z dzieckiem szczęśliwie opuszczę getto. Wtedy odbywały się dantejskie sceny. Na przykład ojciec godził się na oddanie dziecka, a matka nie. Babcia tuliła dziecko najczulej i zalewając się wśród 
szlochu mówiła: „Za nic nie oddam wnuczki!” Czasem opuszczałam tę nieszczęsną rodzinę bez dziecka. Nazajutrz szłam sprawdzić, co się stało z rodziną. I często okazywało się, że wszyscy byli już na Umschlagplatzu (Mieszkowska 2009: 152).

Działaczki społeczne skupione wokół Sendlerowej wypracowały kilka sposobów na wyprowadzenie dzieci z getta. Pierwsza droga ucieczki prowadziła przez korytarze sądów na ul. Leszno, gdyż jedno wyjście z budynku znajdowało się po stronie aryjskiej, a drugie po stronie getta. Sądowi woźni w późniejszym okresie byli również opłacani, żeby na dane hasło otwierać wejście (Grubowska 2014: 45). Dzieci wyprowadzano także przez miejskie kanały i wyrwy w murze getta. Trzecim sposobem ucieczki było przejście przez korytarze remizy tramwajowej na Muranowie, gdzie Sendler i jej współpracowniczkom pomagał zaufany tramwajarz. Małe dzieci wywożono także w samych tramwajach, ukryte w paczkach i skrzynkach. Rano przynoszono paczkę do tramwaju jadącego poza getto, a na umówionym przystanku paczka z dzieckiem była odbierana (Grubowska 2014: 47).

Elżbieta Ficowska, w ten sposób opisuje historię swojego uratowania: W 1942 roku zostałam wywieziona na wozie pełnym cegiet, który wyjeżdżał $z$ getta na aryjska stronę. Między cegłami umieszczono skrzynkę drewniana, która miała otwory. Włożono do niej uśpione luminalem niemowlę, wówczas chyba sześciomiesięczne, z łyżeczka srebrnq na szczęście. Na łyżeczce było moje imię wygrawerowane i data urodzenia. Wcześniej, także dzięki kontaktom pani Ireny, wyprowadzono z getta kilkuletniq moja siostrę cioteczną. Trafitam do pogotowia opiekuńczego zaprzyjaźnionej z Ireną Sendlerową Stanisławy Bussoldowej, położnej, która przychodziła do getta odbierać porody. Miałam u niej zostać kilka tygodni, zostałam na zawsze. Postanowiła mnie zatrzymać. Ponieważ nikt $z$ mojej rodziny nie ocalał, nigdy mnie nie oddała. Wiem, od niej, że moja prawdziwa matka kilka razy opuściła getto, aby mnie zobaczyć. Telefonowała, aby usłyszeć mój głos. Miała dobry wygląd, mogła się uratować, ale nie chciała zostawić swoich rodziców, moich dziadków. Nie mam nawet ich fotografii. Szukam ich przez całe życie, $w$ Polsce i $w$ Izraelu. Dla mnie będa zawsze niezaspokojoną tęsknotą. Niespełnieniem mimo poznanego szczęścia rodzinnego (Mieszkowska 2014: 176).

Podobnie jak historie życia dzieci w getcie, tak okoliczności ich ocalenia były bardzo różne. Michała Głowińskiego i jego rodziców ocalił znajomy, będący żydowskim policjantem, który pomógł wydostać im się z Umschlagplatzu. Głowiński wspomina: Nam przyszedł z pomoca przypadek. Ojciec spotkał od lat niewidzianego znajomego z czasów młodości, który był żydowskim policjantem. Poprosił go, by ułatwił nam wydostanie się. (...) Ów znajomy $z$ dawnych lat wypuścił nas z Umschlagplatzu jakimś bocznym wyjściem, może była to z reszta dziura w ogrodzeniu. Ocaleliśmy, ocaleli moi rodzice, ocalałem i ja (Grubowska 2009: 19). Ostatecznie Głowiński trafił do sierocińca w Turkowicach prowadzonego przez siostry zakonne ze Zgromadzenia Służebniczek Najświętszej Marii Panny, gdzie doczekał końca wojny. Irena Sendlerowa uratowała także matkę Głowińskiego załatwiając jej pracę służącej w domu nauczycielki w podwarszawskim Otwocku (Mieszkowska 2009: 295).

Również Katarzyna Meloch, dzisiaj publicystka i reporterka, ukrywała się w sierocińcu w Turkowicach. Sierociniec ten był ostatnim etapem drogi jej ocalenia po ucieczce z białostockiego getta, którą zaplanowała jej własna matka i uratowaniu z 
Umschlagplatzu przez własną babcię. Meloch wspomina: Zima 1942/43 roku przyszedł zapewne do Turkowic kolejny zaszyfrowany sygnał $w$ niewinnym na pozór liście. $W$ ten sposób Irena Sendlerowa zawiadamiała siostry zakonne, że trzeba zabrać do Turkowic żydowskie dzieci (albo jedno z nich). Siostry ów szyfr odczytywały bezbłędnie. Po takim liście siostra Irena (Antonina Manaszczuk) ruszyła do Warszawy. Przywiozła także i mnie, zima 1942/43 roku. Na naszym szlaku czaiły się różne niebezpieczeństwa. Spędzić trzeba było noc w poczekalni dworcowej w Lublinie lub Rejowcu. Zaglądano w twarze podróżnym, szczególnie dzieciom. A nasza długa podróż przeszła bezpiecznie. Za drzwiami turkowickiego domu dziewcząt z plakatem „Żydzi, wszy, tyfus plamisty” żyły spokojnie uratowane $z$ Holokaustu żydowskie dziewczynki! W bajkowym krajobrazie Zamojszczyzny plakat, znak nienawiści, wydał mi się nierzeczywisty. Nie zlękłam się go wcale (Meloch 2008: 163-164).

Wyjście z getta było zadaniem niezwykle trudnym, jednak dotarcie do kryjówki, nie wspominając już o stworzeniu takich kryjówek, było o wiele trudniejsze. Przy bramie często można było spotkać szantażystów, którzy tylko czekali na możliwość ograbienia uciekających Żydów ze wszystkiego. Kiedy już udało się wymknąć szmalcownikom dzieci umieszczano w tzw. pogotowiu opiekuńczym, czyli miejscu, gdzie dana rodzina starała się złagodzić szok u dziecka, uspokoić je oraz wyposażyć w niezbędne umiejętności konieczne dla zachowania dyskrecji tj. naukę pacierza i nowego, sfałszowanego życiorysu (Grubowska 2014: 48-49). Następnie dzieci były umieszczane w zakładach opiekuńczych. O ile, w przypadku polskich sierot, nie było to tak trudne, to w przypadku dzieci żydowskich stanowiło olbrzymie ryzyko. Przede wszystkim dokumenty dziecka musiały być perfekcyjnie sfałszowane, żeby nie budziły żadnych wątpliwości. Dodatkowym problemem było umieszczanie żydowskich dzieci w zakładach zakonnych. Na tym polu niezwykłe zasługi należy przypisać Janowi Dobraczyńskiemu, przełożonemu Sendlerowej, który dzięki swojej postawie i znajomościom rodzinnym nawiązał osobiste porozumienie z zakładami, gdzie kierowano dzieci. Wszystkie skierowane tam przez niego dzieci (a było ich według szacunków około 700) przeżyły (Grubowska 2014: 34, zob. Bartoszewski, Lewinówna 2007: 102).

Meloch wspomina postać Jana Dobraczyńskiego opisując „łańcuch ocalenia” - takim mianem określano kolejne etapy podczas ratowania dzieci z Holokaustu - dzieci żydowskich: Dobraczyński był kierownikiem tzw. referatu spraw socjalnych Wydziału Opieki Społecznej Zarządu Miejskiego Warszawy. Tu poznała go Irena Sendlerowa. Wspominając akcję umieszczania żydowskich dzieci w sierocińcach i zakładach dla dzieci pisał kilkadziesiąt lat temu: „Mój wkład w tę akcję był minimalny. Nie ja szukałem tych dzieci, nie ja je przewoziłem, nie ja sporządzałem fałszywe wywiady." Moja obecność $w$ turkowickim zakładzie stała się możliwa dzięki tej akcji. (...) Nieliczne ogniwa łańcucha ocalenia były dla ratowanego dziecka widoczne. O niektórych usłyszałam po latach. O innych - nie będę wiedziała nigdy. Każde ogniwo było konieczne. Łańcuch ani na chwilę nie został przerwany. W okresie okupacji oczywiście nie miałam pojęcia o istnieniu „Żegoty”. I nie znałam Ireny Sendler. Poznałam ja po wojnie. Ratowała mnie w latach dziewięćdziesiątych, gdy doznałam odrzucenia $w$ rodzinnym kręgu. Pani Irena pocieszała mnie dzień po dniu, godzina po godzinie. Przekazywała mi cząstkę swego hartu ducha. Jej przyjaźń wspierała mnie i wtedy, gdy trzeba było komuś bardzo bliskiemu podać nie tylko rękę (Meloch 2008: 164).

Irena Sendlerowa była nie tylko ratowniczką i przybraną matką, była także świad- 
kinią wielkiej traumy, którą przeżywały uratowane dzieci. Nagle wyrwane ze swoich domów i środowisk, uczone języka polskiego i religii chrześcijańskiej, żeby jak najlepiej się zakamuflować i ukryć przed okupantami, po wojnie były psychicznie załamane, zagubione i stawały przed kolejnym ogromnym wyzwaniem, jakim był powrót do pierwotnej tożsamości.

Głowiński opisuje swoje spotkanie z matką po wojnie w następujących słowach: Przed kilkunastoma miesiącami rozstanie z matka było dla mnie szokiem, a teraz szokiem, szokiem na swój sposób paraliżującym, okazało się pierwsze spotkanie po wojnie, z której $i$ ona, $i$ ja, cudem uszliśmy z życiem. Nie zrobiłem żadnego właściwego $w$ tak niezwykłej sytuacji gestu, nie rzuciłem się jej na szyję, nie umiałem wyłuskać z siebie ani jednego zdania, które byłoby spontaniczne i zarazem odpowiednie w takich okolicznościach. Dopiero po chwili powiedziałem: Mama, po twoim berecie maszeruje ogromna wesz. Rzeczywiście była to pierwsza rzecz, jaką zauważyłem. Autor tych słów zdaje sobie sprawę, że narusza zasadę stosowności, że opis spotkania matki z synem po wojnie powinien zawierać elementy patetyczne i wzniosłe, jednak jest w swoich wspomnieniach niezwykle konsekwentny i autentyczny.

Podobne wrażenia ze spotkania z matką wyniósł inny ratowany przez Sendler - Piotr Zettinger. Pisze on: Moje wątpliwości potwierdziły się, kiedy zobaczyłem tę czekająca na mnie kobietę. Niczym nie przypominała mamy, której obraz zachowałem $w$ zakamarkach pamięci. (...) Kiedy mnie zobaczyła, podniosła się z krzesła , znowu jednak usiadła i zaczęła płakać. Byłem doświadczonym wojennym dzieckiem, widziałem już nieraz dorosłych, którzy płakali gdyż spotkało ich nieszczęście, zostali pobici lub obrabowani, krwawili z otwartej rany, stracili właśnie swój dom w pożarze albo dowiedzieli się przed chwila o śmierci kogoś bliskiego. Lecz wylewać łzy z tego powodu, że spotkało się swoje dziecko nie, tego zrozumieć nie mogłem. Doszedłem do wniosku, że to na pewno nie moja mama, choć nie odważyłem się tego głośno powiedzieć (Mieszkowska 2009: 347). To wyznanie jasno pokazuje traumatyczne doświadczenie dzieci podczas Holokaustu, ich okaleczenie emocjonalne i zmianę możliwości percepcji pewnych spraw, mogłoby się wydawać podstawowych, takich jak płacz ze szczęścia nad uratowanym dzieckiem.

Ci, którzy jak Głowiński po wojnie wrócili do swoich rodzin mogli uważać się za wybrańców. Wiele dzieci na zawsze zostało oddzielonych od rodziców i bliskich i samodzielnie musiało stawiać pierwsze kroki po ocaleniu. Ta samodzielność była niezwykle trudna.

Katarzyna Meloch w 1946 roku, mając 13 lat, w poradni psychologicznej pisała o swoich życzeniach: (...) Chciałabym bardzo, aby odnaleźli się moi rodzice. Jest to największym moim życzeniem. Trzecim moim życzeniem jest, abym mogła się odwdzięczyć wszystkim tym, którzy dla mnie coś dobrego zrobili, ponieważ uważam to sobie za obowiazek (Meloch 2008: 161). I na innym miejscu pisze: Nauczyłam się w czasie okupacji „kłamać aby żyć". Nauczyłam się zmieniać skórę stosownie do potrzeb chwili. Zło trwało we mnie dalej po wojnie. Czy można wyjść obronna ręka z kilku lat codziennego kłamstwa, z dzieciństwa na cudzych papierach, czy można było wyjść bez szkód wewnętrznych? (Meloch 1993: 96).

O trudnościach związanych z akceptacją prawdy o swoim ocaleniu pisze Elżbieta Ficowska: Miałam siedemnaście lat, kiedy przypadkiem dowiedziałam się, że wszystko, co 
wiem o sobie, jest nieprawdą. Moja mama wcale mnie nie urodziła, tylko zaopiekowała się sześciomiesięcznym niemowlęciem. Rodzice moi i rodzina zginęli, a ja jestem żydowskim dzieckiem uratowanym cudem, który najpewniej by się nie zdarzył, gdyby nie wspaniali ludzie zdolni do najwyższych poświęceń. Moja przybrana mama Stanisława Bussoldowa była położna i współpracowała $z$ „Żegotą”. Była w kontakcie konspiracyjnym z pania Irena Sendlerowa, która robiła wszystko, co w ludzkiej mocy, żeby ratować żydowskie dzieci. Moja przybrana mama odbierała porody od ukrywajacych się Żydówek, przechowywała w swoim domu dzieci, wspólnie z zaufanymi ludźmi wyrabiała im odpowiednie dokumenty $i$ wyszukiwała $w$ polskich rodzinach bezpieczne schronienia dla swoich małych podopiecznych (Ficowska 1993: 234).

W najnowszym swoim tekście o lalkach z czasów wojny z 2015 roku Katarzyna Meloch wspomina o ogromie samotności, jaki towarzyszył uratowanym dzieciom żydowskim: W Turkowicach, domu mego ocalenia - był to zakład dla osieroconych dzieci prowadzony przez siostry zakonne, służebniczki starowiejskie - marzyłam o lalce. Brakowało mi jej bardziej niż rodziców, niż najbliższej sercu babci Michaliny, niż wuja Jacka, brata mojej mamy, który w warszawskim getcie potrafił mi zastapić i ojca, i matkę. Instynktownie czułam, że tylko lalce można powiedzieć o sobie to, co najważniejsze (Meloch 2015: 83).

Te wszystkie lęki, niepokoje, bolączki i ból samotności, które towarzyszyły ocalonym dzieciom doskonale rozumiała również Irena Sendlerowa. Nadal była obecna w ich życiu, a dla niektórych tak naprawdę dopiero zaczynała być obecna, gdyż podczas wojny nie mieli oni wiedzy na temat zasad funkcjonowania wspomnianego wcześniej „łańcucha ocalenia”. Biografka Ireny Sendlerowej pisze: Pani Irena, jako jedna z nielicznych, uratowane dzieci rozumiała, kochała, współczuła im, cieszyła się z ich życiowych sukcesów, martwiła kłopotami zdrowotnymi. Towarzyszyła im $w$ dorastaniu w sposób dla wielu niewidzialny, interesowała się ich nauka, a później pracą zawodowa. (...) Z kilkorgiem uratowanych (...) miała stały kontakt od końca wojny (Mieszkowska 2014: 228-229).

Piotr Zettinger wspomina troskę Ireny Sendlerową wobec uratowanych dzieci: Po wojnie zamieszkaliśmy blisko siebie, nasze rodziny znów się przyjaźniły. Pani Irena miała już własne dzieci, a mimo to traktowała mnie jak syna. To nie było zdawkowe ani takie od święta. (...) Czułem jej prawdziwe zaciekawienie i autentyczna troskę. (...) Na każda Gwiazdkę dostawałem od pani Ireny prezenty. Ostatni raz w ostatnie święta (Mieszkowska 2014: 117).

W podobnym tonie wypowiada się Elżbieta Ficowska: Wzruszające jest to, że ona ciagle troszczy się o te swoje stare dzieci, które kiedyś uratowała. Jest sama $w$ domu opieki Bonifratrów. Troszczy się o to, żeby dzieci miały dom żydowski, skoro nie miały dzieciństwa to powinny mieć godna starość.

Czasami ta nadopiekuńczość budziła sprzeciw i gniew. Tak było w przypadku Teresy Korner (Chai Estery Sztein), która dzięki Sendlerowej i Grobelnemu otrzymała fałszywe dokumenty. Wspominała, że denerwowały ją nadopiekuńczość pani Ireny, która znając dramat jej przeżyć wojennych, chciała zastąić jej matkę. W jednym z listów Teresa napisała: „Wiesz dlaczego byłam dla ciebie taka niedobra, opryskliwa, nieposłuszna? Bo twoja dobroć targała moje serce rozpacza. Myślałam wtedy - kto ci dał prawo zastapić mi moja matkę?” (Nekeda-Trepka 2003: 18:47 minuta filmu).

Z czasem to oblicze matczyne, bardzo intymne i prywatne zostało przyćmione przez 
obraz Ireny Sendler - bohaterki i Sprawiedliwej.

\section{OBLICZE HEROICZNE}

Według Słownika Języka Polskiego bohater to osoba odznaczająca się niezwykłymi cechami i wykazująca się nadludzkim męstwem i odwagą. Tak przedstawiana była Irena Sendlerowa w ciągu ostatnich dwudziestu latach. Z początku zapomniana i nieobecna w dyskursie publicznym została wykreowana na bohaterkę i główną postać ratującą żydowskie dzieci w Polsce. Stała się symbolem i znakiem rozpoznawczym całego ruchu oporu oraz “Żegoty”. Świadczyć o tym mogą liczne inicjatywy honorujące jej wojenne wysiłki oraz przyznane odznaczenia.

Działalność Ireny Sendlerowej przez wiele lat znana była jedynie małemu gronu osób, pośród których znaleźli się ocalone przez nią dzieci, przyjaciele i kilku historyków dziejów Zagłady. We wstępie do pierwszej biografii Sendlerowej autorstwa Anny Mieszkowskiej Głowiński pisze o tym następująco: Rzeczy toczyły się tak, jakby nie tylko nie zdawano sobie sprawy, ale sprawy zdawać sobie nie chciano, że żyje wśród nas osoba o biografii niezwykłej i wielkiej, osoba pomnikowa, można by powiedzieć odwołując się do sławnego wiersza Juliusza Słowackiego, na miarę Fidiasza, choć w życiu codziennym skromna, serdeczna, ludziom życzliwa i zawsze wyciagająca pomocna rękę do tych, którzy sq w potrzebie, osoba, z która kontakt jest po prostu przyjemnościa (Mieszkowska 2009: 7).

Głowiński wskazuje na dwie przyczyny takiego stanu rzeczy: jej pochodzenie oraz wojenną przeszłość. W powojennej rzeczywistości nie było miejsca, dla Sendlerowej, wywodzącej się, co prawda z lewicy, ale lewicy dalekiej utopijnemu komunizmowi. Tym bardziej, ze Sendlerowa poświęciła swoja wojenna działalność na ratowanie Żydów, a wszystko, co łączyło się z Żydami traktowane było w Polsce Ludowej jako temat grząski, niepewny i niebezpieczny, taki, o którym lepiej milczeć niż mówić (Mieszkowska 2009: 8).

Irena Sendlerowa otrzymała tytuł Sprawiedliwej wśród Narodów Świata przyznawany przez jerozolimski Instytut Yad Vashem w dniu 19 października 1965 roku. Jednak ze względów politycznych dopiero w 1983 roku mogła przylecieć do Izraela. Wtedy też odebrała medal, zasadziła drzewko w Alei Sprawiedliwych i spotkała się z uratowanymi przez siebie, mieszkającymi tam, dziećmi (Mieszkowska 2014: 195-197). W roku 1991 Irenie Sendlerowej zostało przyznane honorowe obywatelstwo państwa Izrael. Jednak nawet wtedy postać Sprawiedliwej nie była szeroko znana w Polsce.

W okresie od września 1999 do lutego 2000 roku Megan Stewart, Elizabeth Cambers, Sabrina Coons i Gabrielle Bradbury - cztery uczennice z liczącego niecałe 300 mieszkańców miasteczka Uniontown w stanie Kansas w Stanach Zjednoczonych - pracowały nad projektem olimpiady historycznej (National History Day) opowiadającym historię Ireny Sendlerowej. W lutym 2000 roku wystawiły sztukę teatralną w oparciu o fakty z życia Sprawiedliwej pt. Życie w słoiku (Life in a jar). Inspiracją do podjęcia badań na temat Polki był artykuł Richarda Z. Chesnoffa z 1994 roku. Autor artykułu w nawiązaniu do filmu Stevena Spielberga „Lista Schindlera” przywoływał postaci ratujących Żydów, które nie stały się tak popularne i znane jak sam Schindler. Jedną z 
opisywanych przez Chesnoffa postaci była właśnie Irena Sendlerowa (Chesnoff 1994). Autorkom projektu udało się skontaktować z dziewięćdziesięcioletnią wówczas Ireną Sendlerową. Dziewczęta odwiedziły ją w Polsce, a ona tłumaczyła im okoliczności historyczne swojej działalności wojennej. Korespondencja i kontakt trwały do 2008 r., a dziewczęta wielokrotnie prezentowały swoją sztukę o polskiej bohaterce zarówno w Stanach Zjednoczonych jak i Europie (Mieszkowska 2009: 41-50). Jedno z przedstawień odbyło się w Teatrze Żydowskim w Warszawie w 2005 roku, kiedy amerykańskie byłe uczennice przyjechały po raz kolejny do Polski, już jako dojrzałe kobiety (Mieszkowska 2014: 235).

Ten właśnie projekt i jego popularność sprawiły, że nazwisko Sendlerowej weszło do debaty publicznej i jej osoba stała się swego rodzaju symbolem Polaków ratujących Żydów. Jednocześnie w roku 2000 ukazała się w druku publikacja Jana Tomasza Grossa pt. Sąsiedzi. Historia zagłady żydowskiego miasteczka, która dotyczyła historii miasteczka Jedwabne, gdzie Polacy mordowali Żydów podczas Holokaustu. Publikacja ta stała się impulsem do narodowej debaty na temat postaw Polaków wobec Żydów w trakcie II wojny światowej, ale także w szerszej perspektywie relacji polsko-żydowskich i pamięci w ogóle. Sama Irena Sendlerowa wspominała: Po Jedwabnem potrzebny jest bohater. Pamiętajcie, że nic bym sama nie zrobiła (Mieszkowska 2009: 29) a na spotkaniu promocyjnym własnej biografii mówiła: Po Jedwabnem potrzebny jest bohater. Ale ja do tej roli nie pasuję. Robiłam tylko to, co we mnie od kolebki wpajano. A przede wszystkim mówiono mi, żebym pomagała potrzebującym. Niezależnie od okoliczności (Mieszkowska 2014: 225).

Stowarzyszenie Dzieci Holokaustu postanowiło zgłosić Irenę Sendlerową do pokojowej Nagrody Nobla (Mieszkowska 2009: 29). Starania te kontynuowano w roku 2006 i latach następnych (Kancelaria Prezydenta 2008), kiedy kandydaturę zgłosił Norman Conrad, a poparli ją prezydent RP Lech Kaczyński i premier Izraela Ehud Olmert (RMF24 2006). Podczas oficjalnej wizyty prezydenta Lecha Kaczyńskiego w Izraelu, Ewa Junczyk-Ziomecka - przedstawicielka z Kancelarii Prezydenta, aktywnie zaangażowana w działania na rzecz upamiętnienia Jana Karskiego - tak wypowiadała się w kontekście postawy Ireny Sendlerowej: Wśród nas żyli i żyja w dalszym ciągu bohaterowie, których możemy przeciwstawić tym - może nie tak licznym - którzy nie wytrzymali presji Holokaustu i nie zachowali się tak, jak my wszyscy chcielibyśmy się w tych trudnych sytuacjach zachować. To w pewnym sensie plama na naszej duszy (Kancelaria Prezydenta 2008: Wspomnienie o Irenie Sendler). W liście Prezydenta Kaczyńskiego do Komitetu Pokojowej Nagrody Nobla ze stycznia 2008 roku czytamy: Pokojowa Nagroda Nobla dla Ireny Sendlerowej, o która występuję, byłaby nie tylko hołdem złożonym jej bezprzykładnie bohaterskiej biografii. $W$ jej osobie Komitet uhonorowałby również wszystkich tych, którzy z narażeniem swego życia ratowali ofiary najstraszliwszej zbrodni $w$ dziejach. Ich świadectwo nie może zostać zapomniane, a żyje ich już tak niewielu. Dlatego też wnoszę o Nagrodę dla Sprawiedliwej - w imieniu wszystkich Sprawiedliwych (List nominacyjny do pokojowej nagrody Nobla 2008).

W lipcu 2003 roku działająca przy Amerykańskim Centrum Kultury Polskiej Fundacja Jana Karskiego (w zarządzie której zasiada również Junczyk-Ziomecka) przyznała Irenie Sendlerowej Nagrodę im. Jana Karskiego - „Za Męstwo i Odwagę” (Irena Sen- 
dler była jedna z osób, które eskortowały Jana Karskiego podczas jego pobytu w getcie warszawskim. Zob. Mieszkowska 2009: 126-127). Fakt ten skomentował Natan Gross w artykule „Irena i Jan” słowami: Irena Sendler to wspaniała kobieta, o której mówiono, że jest najjaśniejsza gwiazda na czarnym niebie okupacji w Polsce. Nagrodę imienia Jana Karskiego, którą otrzymała, można by nazwać - nagroda sumienia. Moim zdaniem Irena Sendlerowa i Jan Karski to dwa wielkie nazwiska zasługujące na wieczna pamięć narodu żydowskiego (Mieszkowska 2014: 211-212).

Również w roku 2003 otrzymała Order Orła Białego - najwyższe odznaczenie Rzeczypospolitej Polskiej. Order został jej wręczony przez ówczesnego prezydenta Aleksandra Kwaśniewskiego (Mieszkowska 2009: 35). Od roku 2007 Irena Sendlerowa wchodziła w skład Kapituły Orderu Orła Białego (Kancelaria Prezydenta 2007: Irena Sendler w Kapitule Orderu Orła Białego).

W lipcu rok później miała miejsce promocja pierwszej biografii Ireny Sendlerowej, napisanej wraz z Anną Mieszkowską (Mieszkowska 2014: 223). Michał Głowiński we wstępie do tej publikacji napisał: Irena Sendlerowa jest teraz symbolem heroizmu i poświęcenia - i wszelkie po temu ma dane, by stać się symbolem dobrych, przyjacielskich stosunków łączących społeczność polska ze społecznościa żydowska (Mieszkowska 2009: 9). Popularność książki przybliżyła postać Ireny Sendlerowej szerokiej publiczności, ale także zdezorganizowała ówczesne życie tytułowej bohaterki. Rozpoczęły się liczne wizyty, koleżanek i kolegów, którzy nie wiedzieli o jej przeszłości, oficjeli i delegacji rządowych (jak np. wizyta ambasadora Niemiec z małżonką w 2006 r.) (Mieszkowska 2014: 225 i nast.).

Kolejne nagrody i zaszczyty (Sendler otrzymała honorowe obywatelstwo miasta Warszawy (2007) i Tarczyna (2007), Otwocką Sosenkę (2004), Order Uśmiechu (2007). Została odznaczona także nagrodą humanitarną im. Audrey Hepburn (2009)). umacniały jedynie obraz Ireny Sendlerowej jako wojennej bohaterki, heroiny ratującej żydowskie dzieci. W dniu 14 marca 2007 roku Prezydent RP Lech Kaczyński wziął udział w posiedzeniu Senatu RP. Podczas posiedzenia podjęto specjalną uchwałę mającą na celu uhonorowanie działalności Ireny Sendlerowej i Rady Pomocy Żydom „Żegota”. Prezydent mówił wówczas: Była to wyjątkowa zbrodnia [Holokaust - przyp. KS] $i$ to zbrodnia popełniana $w$ warunkach niewyobrażalnego terroru wobec tych, którzy chcieliby Żydom, bądź Polakom żydowskiego pochodzenia pomóc. Za to groziła śmierć zarówno osobie, która na taka pomoc się decydowała, jak i członkom jego rodziny. O tym należy pamiętać. Ale takie osoby $w$ naszym społeczeństwie się znalazły. Ich symbolem może być Irena Sendlerowa, żyjąca na szczęście do dziś, choć liczy już ponad 90 lat. Uratowała ona ponad dwa tysiące żydowskich dzieci. Irenę Sendlerowa należy traktować jako wielka bohaterkę, jako osobę, którą w sposób w pełni zasadny można zgłosić do Pokojowej Nagrody Nobla. Jednocześnie jednak jest ona pewnym symbolem - symbolem grupy ludzi, których było nieporównanie więcej niż jedna, wyjątkowo bohaterska Irena Sendlerowa - to Sprawiedliwi Wśród Narodów Świata. Jest ich ponad 6 tysięcy. To ludzie, którzy w różnych okolicznościach na terenie Polski, zawsze z narażeniem życia, ratowali Żydów lub osoby żydowskiego pochodzenia. Należy im się od nas wszystkich, od naszego narodu szczególny szacunek za bohaterska postawę, szczególny szacunek za to, że byli reprezentantami naszego honoru (Kancelaria Prezydenta 2007: Irenę Sendlerową należy traktować jak 
wielką bohaterkę). Odpowiedź Ireny Sendler była niezwykle skromna: Dziękuję za wyróżnienie przyznane przez Panie i Panów Senatorów. Każde uratowane dziecko żydowskie przy moim udziale i tych wszystkich wspaniałych łączniczek, które dziś już nie żyja jest usprawiedliwieniem mojego istnienia na tej ziemi. Nie tytułem do chwały (Kancelaria Prezydenta 2007: Irenę Sendlerową należy traktować jak wielką bohaterkę).

Od 2006 roku przyznawana jest nagroda im. Ireny Sendlerowej „Za naprawianie świata”. Nagroda ta powstała z inicjatywy Stowarzyszenia Dzieci Holokaustu i Fundacji Life in a Jar przy wsparciu Ministerstwa Spraw Zagranicznych. Osobami mogącymi otrzymać to wyróżnienie są nauczyciele z Polski i Stanów Zjednoczonych, którzy uczą tolerancji i szacunku wobec innych. Laureatami pierwszej edycji zostali Norman Conrad i Robert Szuchta.

Irena Sendlerowa stała się również patronką dla 30 polskich szkół i 3 szkół niemieckich (Mieszkowska 2014: 311-312). Tym samym jej działalność i ona sama została explicite wzorcem do naśladowania dla młodych pokoleń.

Irena Sendlerowa mówiła skromnie o swojej działalności podczas II wojny światowej. Już podczas spotkania w Muzeum Yad Vashem w 1983 roku wspominała: Kiedy więc zbrodniarze niemieccy - hitlerowscy postanowili wymordować naród żydowski, nie mogłam na to patrzeć obojętnie. (...) Nieprawda jest, że to było bohaterstwo. To nie żadne bohaterstwo, a tylko zwykła naturalna potrzeba serca (Mieszkowska 2014: 259) i znowuż Kończąc, pragnę jak najmocniej podkreślić, że nie my, ratujacy, jesteśmy jakimiś bohaterami (te słowa odnośnie nas nawet mnie bardzo drażnia). Odwrotnie - ciagle mam wyrzuty sumienia, że tak mało zrobiłam. Bohaterami matczynych serc są dzieci żydowskie, które niejednokrotnie musiały wyrzekać się swoich matek i ojców - aby żyć! (Mieszkowska 2014: 270-271).

Wzrost zainteresowania tematyką Polaków ratujących Żydów, w tym także Sprawiedliwych wśród Narodów Świata nie odbywał się w próżni. Z jednej strony już w latach 90-tych XX wieku w Polsce, po upadku komunizmu, temat relacji polsko-żydowskich powrócił do debaty publicznej (zob. Potel 2010). Był to czas kiedy do głosu dochodzi młode pokolenie naukowców, które nie bało się zadawać trudnych pytań o przeszłość. Wolność słowa pozwoliła na rozwój badań naukowych i możliwość publikacji ich wyników. Z czasem rozwinęły się silne ośrodki naukowo-badawczo-edukacyjne, które sukcesywnie wypełniały lukę badawczą. Warto przywołać tutaj choćby Centrum Badań nad Zagładą Żydów w Warszawie czy Instytut Judaistyki Uniwersytetu Jagiellońskiego w Krakowie. W 1989 r. Holokaust został wpisany w podstawę programową i stał się obowiązkowym tematem nauczanym w szkołach. Początek XXI wieku naznaczyła wspomniana debata dotycząca Jedwabnego oraz cykl książek naukowców związanych z ww. Centrum dotyczący zabijania Żydów przez Polaków w tzw. trzeciej fazie Holokaustu. Zmiany te zbiegły się z rosnącym zainteresowaniem Unii Europejskiej tematyką pamięci i edukacji o Holokauście. W 2005 roku ustanowiono Dzień Pamięci o Holokauście a w 2013 Dzień Pamięci o Sprawiedliwych. Rozliczenie z trudną przeszłością stało się swoistym warunkiem wejścia do wspólnoty narodów europejskich (Judt 2006). Historie Sprawiedliwych, w tym także Ireny Sendlerowej czasami stawały się odpowiedzią na niemożność pogodzenia się z czarnymi kartami relacji polsko-ży- 
dowskich podczas Holokaustu. W tym kontekście głębokiego znaczenia nabiera uwaga prof. Tokarskiej-Bakir: Pani Irena Sendler powiedziała kiedyś, że nie chce, aby jej nazwiskiem podpierano się na akademiach, a jej okupacyjna działalność stała się usprawiedliwieniem dla zła. Dlatego nie zgadzała się na wywiady. Odpowiedziała dziennikarzowi z USA, który ja przekonywat, że cały świat powinien usłyszeć od niej świadectwo prawdy: „Cały świat? Czy cały świat mi pomagał, gdy ratowałam te dzieci? Gdy szłam ulica i płakałam z bezsilności?” (Isakiewicz i in. 2005:66).

\section{ZAKOŃCZENIE}

W świetle powyższych rozważań łatwo zauważyć, że obydwa oblicza Ireny Sendlerowej są uproszczone i niepełne. Wizja matki ratującej i nieustannie opiekującej się uratowanymi żydowskimi dziećmi jest tylko częścią prawdy, gdyż Irena Sendlerowa nie działała w pojedynkę, a wręcz przeciwnie, była jednym z ogniw (kluczowym, ale nie jedynym) „Żegoty”. Dodatkowo aspekt funkcjonowania w większej strukturze był zawsze przez nią podkreślany. Ponadto kreowany wizerunek matki znalazł swoje odzwierciedlenie de facto, dopiero po wojnie, kiedy wiele uratowanych dzieci dowiedziało się o udziale Sendlerowej w procesie ich ratowania i kiedy ona sama zaistniała w ich życiu.

Sendlerowa nie określała swoich działań jako matczynych odruchów, wyraźnie mówiła, że kierował nią odruch ludzki. Podkreślała swoją odrębność, wyraźnie akcentując istnienie i bohaterstwo matek (rodziców) uratowanych dzieci. Nie uzurpowała sobie prawa do bycia zastępczą matką, mimo iż wielu ocalonych w taki sposób ją postrzegało.

Podobnie wizerunek bohaterki wydaje się być uproszczony. Irena Sendlerowa nigdy nie podejmowała prób kreowania się na heroinę. Przez lata jej historia nie była znana i właściwie dzięki działaniom osób spoza Polski stała się powszechnie znana. W nadmiernym tworzenia wizerunku heroicznego dodatkowo kryje się niebezpieczeństwo generalizacji i przypisywania Polakom podczas Holokaustu jedynie postaw bohaterskich zapominając o zachowaniach haniebnych, które zostały wielokrotnie dowiedzione.

Sendlerowa z pewnością zdawała sobie sprawę, że jej działania służą także partykularnym celom. Jasno mówiła o tym, że po Jedwabnem potrzebny jest bohater. Nie chciała tej roli odegrać. W swoich wypowiedziach pozostawała skromna, nieustannie przypominała, że funkcjonowała w ramach szerszej struktury, że stanowiła tylko jedno ogniwo w “łańcuchu przeżycia”.

Irena Sendlerowa była z pewnością wspaniałą społeczniczką, Sprawiedliwą, dzięki działalności której wiele dzieci żydowskich ocalało z Holokaustu. Jednak historia jej życia to znacznie więcej niż przedstawione tutaj wizerunki. Można nawet powiedzieć, że wizerunki Sendlerowej z czasem zaczęły funkcjonować niezależnie od niej samej. Pozostaje odpowiedzieć sobie na pytanie, czy jako społeczeństwo mamy prawo do zamykania danej osoby w kategoriach, na które ona sama się nie zgadza. 


\section{BIBLIOGRAFIA}

Bartoszewski, Władysław. 2015. Życie trudne, lecz nie nudne. Ze wspomnień Polaka w XX wieku. Kraków: Wydawnictwo Znak.

Bartoszewski, Lewinówna (red.). 2007. Ten jest z ojczyzny mojej. Warszawa: Wydawnictwo Świat Książki.

Bogucka, Maria. 2014. Matka Polka. W: Z. Najder, A. Machcewicz, M. Kopczyński, R. Kuźniar, B. Sienkiewicz, J. Stępień, W. Włodarczyk (red.). Węzły pamięci niepodległej Polski. Kraków, Warszawa: Fundacja Węzły Pamięci, Muzeum Historii Polski, Wydawnictwo Znak, s. 449-452.

Chesnoff, Robert. 1994. The Other Schindlers. „U.S. News \& World Report”. 21.03.1994. Engelking, Barbara, Leociak, Jacek. 2001. Getto warszawskie. Przewodnik po nieistniejacym mieście. Warszawa: Wydawnictwo Stowarzyszenie Centrum Badań nad Zagładą Żydów.

Ficowska, Elżbieta. 1993. „Dzieci Holokaustu mówią...” Warszawa: Biblioteka Midrasza, Stowarzyszenie Dzieci Holokaustu w Polsce.

Głowiński, Michał. 2014. Czarne sezony. Kraków: Wydawnictwo Literackie.

Grubowska, Halina. 2014. Ta, która ratowała Żydów. Rzecz o Irenie Sendlerowej. Warszawa: Wydawnictwo Żydowski Instytut Historyczny.

Isakiewicz, Elżbieta, Katarzyna Meloch, Joanna Tokarska-Bakir, Paweł Machcewicz. 2005. Dlaczego nie znamy naszych bohaterów - dyskusja. „Więź” 4 (558): 55-70.

Judt, Tony. 2006. Postwar. A History of Europe Since 1945. London: Vintage Books.

Kunert, Andrzej Krzysztof. 2002. „Żegota” Rada pomocy Żydom 1942-1945. Warszawa: Wydawnictwo Rytm.

Meloch, Katarzyna. 1993. „Dzieci Holokaustu mówią...” Warszawa: Biblioteka Midrasza, Stowarzyszenie Dzieci Holokaustu w Polsce.

Meloch, Katarzyna. 2015. I lalki mają swoje losy.„Więź” 4 (2015): 76-84.

Meloch, Katarzyna. 2008. Scenariusz mojego ocalenia wymyśliła matka. „Dzieci Holokaustu mówią” Warszawa: Biblioteka Midrasza, Stowarzyszenie Dzieci Holokaustu w Polsce.

Mieszkowska, Anna. 2004. Matka dzieci Holokaustu. Historia Ireny Sendlerowej. Warszawa: Wydawnictwo MUZA S. A.

Mieszkowska, Anna. 2009. Dzieci Ireny Sendlerowej. Warszawa: Wydawnictwo MUZA S. A.

Mieszkowska, Anna. 2014. Prawdziwa historia Ireny Sendlerowej. Warszawa: Wydawnictwo Marginesy.

Potel, Jean Ives. 2010. Koniec niewinności. Polska wobec swojej żydowskiej przeszłości, Kraków: Wydawnictwo Znak.

\section{FILM}

Łyżeczka życia, Michał Nekeda-Trepka (reż.), 2003. 
ŹRÓDŁA INTERNETOWE

Irena Sendler kandydatkq do pokojowego Nobla?, 12.09.2006, http://www.rmf24. $\mathrm{pl}$ /fakty/polska/news-irena-sendler-kandydatka-do-pokojowego-nobla,nId,75415\#utm_source=paste \&utm_medium=paste \&utm_campaign=chrome [dostęp 29.09.2016].

Irena Sendler nominowana do nagrody Nobla, 14.12.2006, http://www.rmf24.pl/fakty/ polska/news-irena-sendler-nominowana-do-nagrody-nobla,nId,173334 [dostęp 29.09.2016].

Irena Sendler w Kapitule Orderu Orła Białego, 9.05.2007, http://www.prezydent.pl/archiwum-lecha-kaczynskiego/aktualnosci/rok-2007/art,149,448,irena-sendler-w-kapitule-orderu-orla-bialego.html [dostęp 29.09.2016]

Irenę Sendlerowa należy traktować jak wielka bohaterkę, 14.03.2007, http://www.prezydent.pl/archiwum-lecha-kaczynskiego/aktualnosci/rok-2007/art,149,64,irene-sendlerowa-nalezy-traktowac-jako-wielka-bohaterke.html [dostęp 29.09.2016].

Life in a Jar http://www.irenasendler.org/ [dostęp 29.09.2016]

List nominacyjny do pokojowej nagrody Nobla, 28.01.2008, file://C:/Users/Spiderman/Downloads/list_nominacyjny_do_pokojowej_nagrody_nobla.pdf [dostęp 29.09.2016].

Wspomnienie o Irenie Sendler, 12.05.2008, http://www.prezydent.pl/archiwum-lecha-kaczynskiego/aktualnosci/rok-2008/art,148,403,wspomnienie-o-irenie-sendler.html [dostęp 29.09.2016].

Oficjalna strona Muzeum Historii Żydów Polskich

http://www.sprawiedliwi.org.pl/pl/cms/irena-sendler/ [dostęp 29.09.2016]

Oficjalna strona Instytutu Yad Vashem, http://www.yadvashem.org/yv/en/righteous/ stories/sendler.asp [dostęp 29.09.2016]

\title{
The faces of Irena Sendlerowa. The image of the Righteous Among the Nations in the accounts of the children she saved and in the pub- lic debate after 2000
}

\begin{abstract}
The article aims to analyze the transformation of the image of Irena Sendlerowa - Righteous Among the Nations, activist of the Council for Help Jews „Żegota”. Two faces of Sendler were highlighted in the work - motherly, such as those saved by her saved children, and heroic - created in public space after 2000. In the article her character was shown against the background of changes in the perception of Polish-Jewish relations in Poland.
\end{abstract}

KEYWORDS: Irena Sendlerowa, children, Righteous Among the Nations, Holocaust, saving Jews 
